\title{
FROM SOCIOLINGUISTICS \\ TO COMMUNICATIVE LANGUAGE TEACHING
}

\section{Syafiyah}

Ketua Jurusan Bahasa dan Sastra Inggris

Fakultas Humaniora dan Budaya, Universitas Islam Negeri (UIN) Malang.

Jalan Gajayana No. 50 Telepon (0341) 570872, Faksimile (0341) 570872 Malang 65144.

\begin{abstract}
Abstrak
Aliran Sociolinguistik sebagai respon dari aliran linguistik yang dipelopori oleh Chomsky memberikan pandangan baru terhadap hakekat bahasa. Menurut aliran ini bahasa tidak dipandang sebagai aturan-aturan gramatikal formal semata, tetapi lebih sebagai alat komunikasi. Memahami bahasa manusia berarti memahami bagaimana manusia berkomunikasi satu sama lain dan bagaimana proses komunikasi terjadi. Memahami hakekat bahasa sama saja dengan memahami bagaimana bahasa itu berfungsi di tengah masyarakat. Menguasai bahasa berarti memiliki kompetensi komunikatif, yaitu kemampuan untuk menggunakan bahasa dengan benar dan tepat sesuai dengan konteks sosial. Kompetensi komunikatif meliputi kompetensi linguistik, kompetensi sosiolinguistik, kompetensi wacana dan kompetensi strategis. Dalam ranah metodologi pembelajaran bahasa, aliran tersebut melahirkan pendekatan pembelajaran bahasa komunikatif (Communicative Approach).
\end{abstract}

\section{Kata Kunci}

Sosiolinguistik, Pembelajaran Bahasa Komunikatif 


\section{Introduction}

The interest in studying language in its socio-cultural context arose as a response to linguistic theory proposed by Chomsky (1965), which was concerned mainly with the grammaticality of sentences of an ideal speaker-hearer and the linguistic competence of human beings. Chomsky's theory of linguistics was limited to analyzing those aspects of language which belonged to the realm of form, the structure of the language. His concept of competence was restricted to linguistic or grammatical competence focusing merely on what can be said in language. To understand human language, to him, is to ask what it is, not how or for what purpose it is used. This theory was later considered inadequate by a number of linguists who regard studying language in its social context as important.

Some socially-oriented linguists, one of whom was Hymes, then attempted to build alternative conceptions of language, with particular attention to the study of language and its social function. What language is, Hymes argues, cannot be separated from how and why it is used, and that considerations of use are often prerequisite to recognition and understanding of much of linguistic form. The study of language should therefore be shifted from focus on structure to focus on function -from focus on linguistic form in isolation to linguistic form in human context, the province of sociolinguistic study (Hymes, 1974: 76-77).

This paper provides a brief overview of the theory of Sociolinguistics, -the study of language in society,- and its influence on the domain of language learning and teaching.

\section{Sociolinguistics and Ethnography of Speaking}

The term 'sociolinguistics' began to gain popularity in 1960's (Hymes, 1974). This term has been used as an umbrella for various kinds of studies which relate the study of language to the analysis of any aspects of social life. 
Sociolinguistics is concerned with "investigating the relationships between language and society with the goal being a better understanding of the structure of language and how languages function in communication" (wardhaugh, 1986: 13). In slightly different way Trudgill (1992: 68) defines sociolinguistic study as "work which is intended to achieve better understanding of the nature of human language by studying language in its social context and/or to achieve a better understanding of the nature of the relationship and interaction between language and society." Sociolinguistics may refer to either the use of linguistic data and analyses in other disciplines,concerned with social life or to the use of social data and analyses in linguistics (Hymes, 1974: vii). Sociolinguistics includes such subjects as anthropological linguistics, dialectology, discourse analysis, geolinguistics, secular linguistics (or Labovian sociolinguistics), ethnography of speaking, et cetera (Trudgill, 1992).

Sociolinguistics has been used in a very broad sense to cover many fields of study. It may mean different things to different people, depending on their interest in approaching the nature of the link between language and society. Despite its wide coverage, Hymes (1974: 195-196) identifies three main orientations of practitioners of sociolinguistics; "the social as well as the linguistic", "socially realistic linguistics", and "socially constituted linguistics" orientations. The first category refers to sociolinguistic study with practical goals, such as work relating language to education, certain groups of people, or language policies. Sapir's semantic research for an international auxiliary language, and Bloomfield's work in the teaching of reading are two studies belonging to this category. The second orientation is "work that extends and challenges existing linguistics with data from the speech community". This kind of study may result in completely new and different findings about language from previous studies. The third category refers to studies intended to identify social functions and to discover the ways in which linguistic features are selected and grouped together to serve the social functions. This category of linguistics is concerned with social as well as referential meaning, and with language 
as part of communicative conduct and social action. This includes any studies of the use of language with a specific communicative situation in a special social context.

Since sociolinguistics refers to such a wide range of studies, I would limit my self to elaborate the notion of sociolinguistics in terms of ethnography of speaking, which is more socially-constituted oriented. Following Hymes, ethnography of speaking is understood as "a theory of speech as a system of cultural behavior. ... A system [which is] concerned with the organization of diversity" (1974: 89). It studies the rules for using language in accordance with the social-cultural context in which the language is spoken, and is aimed at discovering regularities in language use.

The speech theory in ethnography of speaking deals with the notion of ways of speaking, speech community, speech situation, speech event, speech act, components of speech events and acts, rules of speaking, and functions of speech (Hymes, 1974: 45-65)

Ways of speaking refers to the relationships among speech events, acts, and styles, on the one hand, and personal abilities and roles, contexts and institutions, and beliefs, values, and attitudes on the other. Speech community is a community sharing knowledge of rules for the conduct and interpretation of speech. Speech situations are the situations associated with speech or in which speech takes place, such as ceremonies, fights, meals, and so on. Speech event refers to activities or aspects of activities that are directly governed by rules or norms for the use of speech conversations, prayers are the examples of speech event. Speech act is the minimal unit of analysis of conversational interaction, such as greetings, jokes, commands, and the like. Components of speech includes message form and content, setting, scene, speaker or sender, addressor, hearer, addressee, purposes, key, channels, forms of speech, norms of interaction and interpretation, and genres or categories such as myth, poem, tale, advertisement, formal letter, and so on. To make the set of components easier to bear in mind, Hymes uses the acronym SPEAKING, standing for setting and scene $(\mathrm{S})$, participants $(\mathrm{P})$, ends $(\mathrm{E})$, 
key (K), instrumentalities (I), norms of interaction and interpretation $(\mathrm{N})$, and genres $(\mathrm{G})$. Rules (relations) of speaking is related to certain guidelines of the local system of speaking. A change in any of the components of speaking will influence the rule of speaking. The last is functions of speech. The speech functions are derived from the purposes and needs of the people involved in social interaction and can be stated in terms of relations among components. For example, poetic function may require a certain choice of code, topic, and message form in a particular period or society.

All of these are the principal concerns of the ethnography of speaking. That there are so many factors to be taken into account in the process of communication shows us the complexity of the process itself.

Language is a tool of communication. The primary function of language is to facilitate human beings with the ability to communicate. Understanding human's language is therefore understanding human's communication, how people communicate with each other, how communication takes place, and how people gain communicative competence.

The central part of ethnographic approach in sociolinguistic study is the concept of communicative competence, which is dealt with in the following section.

\section{Communicative Competence}

The term 'communicative competence' was coined by Hymes to expand the meaning of Chomsky's 'competence' which has been considered too narrow. Hymes (Romaine, 1984:2) defines communicative competence as "the knowledge of sentences, not only as grammatical but also appropriate". Communicative competence is the knowledge of when to speak, when not, and what to talk about with whom, when, where and in what manner. It is one's ability to accomplish a repertoire of speech acts, to take a part in speech events, and to evaluate her/his accomplishment by others. 
In Hyme's view (Richards and Rodgers, 1986:70), a person who acquires communicative competence acquires both knowledge and ability for language use with respect to: 1) whether (and to what degree) something is formally possible, 2) whether (and to what degree) something is feasible in virtue of the means of implementation available, 3) whether (and to what degree) something is appropriate (adequate, happy, successful) in relation to a context in which it is used and evaluated, and 4) whether (and to what degree) something is in fact done, actually performed and what its doing entails.

Another elaboration of the notion of communicative competence is found in Canale and Swain (Richards and Rodgers, 1986:71). They identified four dimensions of communicative competence; grammatical competence, sociolinguistic competence, discourse competence, and strategic competence. Grammatical competence refers to the grammatical and lexical capacity. Sociolinguistic competence is an understanding of the social context in which communication takes place. Discourse competence refers to the interpretation of individual message elements in terms of their interconnectedness and of how meaning is represented in relationship to the entire discourse or text. Strategic competence deals with the coping strategies that communicators employ to initiate, terminate, maintain, repair, and redirect communication.

In addition, Saville-Troike (1982:26) comes up with the communicative components that should be shared by the speakers in order to speak appropriately:

1) Linguistic knowledge
a) verbal elements
b) non-verbal elements
c) patterns of elements in particular speech events
d) range of possible variants (in all elements and their organization)
e) meaning of variants in particular situations.

2) Interactional skills

a) perception of salient features in communicative situations 
b) selection and interpretation of forms appropriate to specific situations, roles, and relationships (rules for the use of speech)

c) Norms of interaction and interpretation

d) Strategies for achieving goals

3) Cultural knowledge

a) Social structure

b) Values and attitudes

c) Cognitive map / schema

d) Enculturation processes (transmission of knowledge and skills)

In short, communicative competence means more than linguistic competence, in that it also takes into account the cultural and social dimension of language.

Grammatically well-formed utterances do not always satisfy the communicative needs of individuals. To exemplify, in Javanese, the choice of appropriate and acceptable language is also determined by who speaks to whom, about whom. One's utterance "Aku arepe dahar" is grammatically correct. Nonetheless, the use of the word 'dahar' for ' $a k u$ ' is regarded as inappropriate, since one is not supposed to use high level of words for her or himself.. Another example of the importance of appropriate selection of language is a conversation between an Indonesian and a foreigner in the folowing context:

Indonesian: "Hello, Sir. Where are you going?"

Foreigner: "It's none of your business".

In Indonesian language it is quite common to address such questions as "Mau kemana?", "Dari mana?" just to mean to greet. In English, however, greeting expressions, such as "Hello, good morning.", "How are you?" are more preferable.

This illustration proves that being communicative competent involves understanding language in terms of the use of the language in 
social context and how the language is used by its speaker, not solely understanding it through the formal rules of the language.

\section{Language Function}

Understanding language in its social context cannot be separated from understanding the functions of language. The functions of language provide the primary dimension for characterizing and organizing communicative processes and products in a society. Without understanding why language is being used as it is, and the effects of such use, it is impossible to understand its meaning in the context of social interaction (Saville-Troike, 1982).

The main function of language, according to Saville-Troike (1982), is that it unifies its speakers as members of a single speech community and excludes outsiders from intragroup communication.

Halliday (Kress, 1976: 17, Richards and Rodgers, 1986:70-71) has elaborated the theory of language functions, based on the generalized social functions of language in the context of the young child's life. He classifies the functions into seven basic language functions:

- the instrumental function (using language to get things),

- the regulatory function (using language to control behavior of others),

- the interactional function (using language to create interaction with others),

- the personal function (using language to express personal feelings and meanings),

- the heuristic function (using language to learn and to discover),

- the imaginative (using language to create a world of the imagination), and

- the representational (or informative) function (using language to communicate information). 
Halliday believes, when the child has acquired the ability to use language to some extent in one of these functions, however limited the grammatical and lexical resources he can use, he has built up a network of options, a meaning potential for that function, and can manipulate some structural arrangement of elements relating to the function.

There are some other ways of labeling the major functions expressed in language. Wilkins (Finochiaro and Brumfit, 1980: 23) suggests the following categories:

- modality (to express degrees of certainty, necessity, conviction, volition, obligation, and tolerance),

- moral discipline and evaluation (judgement, approval, disapproval)

- suasion (persuasion, recommendations, predictions),

- argument (relating to the exchange of information and views),

- rational inquiry and exposition (authors'note: similar in subcategories to argument and evaluation),

- personal emotions (positive and negative),

- emotional relations (greetings, flattery, hostility), and

- interpersonal relations (politeness and status: degree of formality and informality).

Van Ek (Finochiaro and Brumfit, 1980: 23) distinguishes six main functions of communication;

- imparting and seeking factual information (identifying, reporting, correcting, asking),

- expressing and finding out emotional attitudes (expressing and inquiring about agreement and disagreement, accepting or declining an offer or invitation, etc),

- expressing and finding out moral attitudes (pleasure or displeasure, surprise, hope, intentions, etc),

- getting things done (suggesting a course of action, advising, warning), and 
- socializing (greeting and leaving people, attracting attention, proposing a toast)

In addition, Finochiaro and Brumfit (1983: 23-24) propose five broad categories of communicative functions; personal, interpersonal, directive, referential, and imaginative. The personal function refers to the speaker's or writer's ability to clarify his thinking and feelings. The interpersonal function is to establish and maintain desirable social and working relationships. The directive function refers to the use of language to make requests or suggestions, to persuade or to convince. The referential or metalinguistic function is concerned with speaking or writing about the present, the past, or the future, the immediate environment and language itself. Thus, this function will include translation from one language to another. The imaginative function deals with the ability to use language creatively such as composing poetry, writing plays and essays.

Regardless of different ways of categorizing the language functions, what is obvious is that there is more to understanding how language is used than just describing structural elements of sentences. Knowing to use a language means understanding how to use it in order to do things with language, understanding how language serves certain functions and how certain functions are realized in a language.

"Can you open the door?" is formally a question. However, the speaker of English understands that it is not just a question requiring a reply "yes" or "no", but is a request to do something, which requires someone to give a response by doing what $\mathrm{s} / \mathrm{he}$ is supposed to do.

\section{Communicative Competence and Language Acquisition}

It has been pointed out that language cannot be understood merely in terms of its structure; its sound system, its morphological system, or its grammatical system. The study of linguistic system in itself will not picture the notion of language as it is used by the speakers, the owners of the language, in which language is perceived as a tool of 
communication. Thus, learning a language does not simply mean learning the formal structure of the language. Acquiring language is not merely acquiring linguistic competence, but is to achieve communicative competence. Language learners should, consequently, gain knowledge on how to use language in an appropriate manner; how to say greet, how to request politely, how to ask and give suggestion. The appropriate choice will depend on where, when, and to whom the speaker speaks. If the speaker does not have this knowledge, how advanced his linguistic competence is, s/he cannot function completely successfully in the community where the language is spoken.

How can, then, such communicative competence be achieved by the speaker of a particular language? Unlike Chomsky's view of competence, assuming that children are innately equipped with a language acquisition device to allow them internalize language rules (Chomsky, 1965), Hymes' and others' theory of competence assumes that "grammar which the child internalizes is shaped in important ways through socialization into a particular speech community which uses language in culturally specific ways" (Romaine, 1984: 256).

Language varies from one society to another, from one culture to another culture. The uses of language which a child acquires will be determined by the functions which a language serves in a culture. What may be acceptable in one community, may not be in another. Accordingly, communicative competence can only be acquired through socialization into a particular community in which the language is spoken.

\section{Communicative Language Teaching}

Hymes' concept of communicative competence and Halliday's theory of language functions have shed light on language teaching methodology. The theory led to the emergence of communicative language teaching, -also called communicative approach and functional approach,- in 1970's, replacing the existing methods of the date ( e.g. the Audio-lingual Method and Situational Language Teaching). Since then, 
the focus of language teaching has shifted from focusing on form -i.e. acquiring linguistic competence- to focusing on function.

To this approach, the ultimate goal of language learning and teaching should be to develop communicative competence, which involves being able to use the language appropriately to a given social context (Richards and Rodgers, 1986, Larsen-Freeman, 1986). To do this, language learners need to know the linguistic forms, meanings, and functions. They need to know that different linguistic forms can be used to perform one function, and one form may express different functions.

The communicative approach in language teaching is largely based on the theory of language as communication, which starts from a communicative model of language and language use to be applied in the instructional design. It has the following characteristics: 1) Language is a system for the expression of meaning, 2) the primary function of language is for interaction and communication. 3) the structure of language reflects its functional and communicative uses, 4) the primary units of language are not merely its grammatical and structural features, but categories of functional and communicative meaning as exemplified in discourse. (Richards and Rodgers, 1986: 71), and 5) All these features of the communicative language teaching reflect the underlying belief that language is understood more as communication. Hence, prior attention is not merely devoted to grammatical aspect, but also to the functional and communicative dimension of language. These principles become the foundations on which the instructional design and classroom practices based.

\section{Conclusion}

The emergence of sociolinguistic perspective in understanding the nature of human language has led us to an understanding that talking about language is more than just talking about grammatical system. Language is a complex system which also involves the social and cultural aspects. On this ground, to learn a language means to learn how the language is used by its speaker. $\square$ 


\section{BIBLIOGRAPHY}

Chomsky, N. 1965. Aspects of The Theory of Syntax. Cambridge: The MT Press

Finocchiaro, Mary and Brumfit, Christopher. 1983. The Functional-

Notional Approach: From Theory to Practice. Oxford: Oxford University Press 
Hymes, Dell. 1974. Foundations in Sociolinguistics: An Ethnographic Approach. Philadephia: The University of Pennsylvania Press

Kress, G.R. (ed). 1976. Halliday: System and Function in Language. London: Oxford University Press

Larsen-Freeman, Diane. 1986. Techniques and Principles in Language Teaching Oxford: Oxford University Press

Richards.Jack.C. and Theodore, Rodgers, S. 1986. Approaches and Methods in Language Teaching: A Description and Analysis. Cambridge: Cambridge University Press

Romaine, Suzanne. 1984. The Language of Children And Adolescents: The Acquisition of Communicative Competence. Oxford: Basil Blackwell Publisher

Saville-Troike, Muriel. 1982. The Ethnography of Communication: An Introduction. Oxford: Basil Blackwell

Trudgill, Peter. 1992. Introducing Language and Society. London: Penguin English

Wardhaugh, Ronald. 1986. An Introduction to Sociolinguistics. Oxford: Blackwell 